\title{
AGO4 wt Allele
}

National Cancer Institute

\section{Source}

National Cancer Institute. AGO4 wt Allele. NCI Thesaurus. Code C84497.

Human AGO4 wild-type allele is located is located in the vicinity of 1 p34.3 and is approximately $50 \mathrm{~kb}$ in length. This allele, which encodes protein argonaute-4, is involved in RNA recognition and metabolism. 